\title{
THE UNCOLLECTED LETTERS OF HAMLIN GARLAND TO WALT WHITMAN
}

\author{
KenNeTh M. Price \\ ROBERT C. LEITZ, III
}

Writing to Horace Traubel on 14 January 1892, Hamlin Garland noted that the favorable critical response to Main-Travelled Roads (1891) advanced Walt Whitman's own cause: "The best part of my success," Garland remarked, "is that it has come while I am doing a work whose spirit is in part Whitman's and thoroughly reformatory. . . . Whitman's prophecies are be[ing] realized not in the exact form in which he seemed to expect them but in spirit and interior purpose."1

The story of how Garland-so different in sensibility from Whitmancame to regard himself as one of the poet's disciples is only partially understood because many of Garland's papers either have been left unpublished or they have been, by modern standards, poorly edited. Of the dozen extant letters from Garland to Whitman (written from 1886 to 1890) five have never been published; the seven that have been previously published appeared either in Traubel's With Walt Whitman in Camden or in Garland's own Roadside Meetings. ${ }^{2}$ Both Traubel and Garland were careless when transcribing documents for publication, and of course they provided no annotations for letters. The twelve letters collected here, together with the recent publication in the Walt Whitman Quarterly Review of the "Walt Whitman" chapter of Garland's fragmentary history, "The Evolution of American Thought," 3 provide primary materials for a better understanding of the Whitman-Garland relationship.

These letters do more, however, than merely illuminate one literary relationship. Perhaps most intriguingly, they clarify how Whitman's followers turned defeat in Boston into a major victory. For Whitman to gain a sympathetic hearing in Boston was no small local matter; it was in the Gilded Age, as Martin Green has shown, that New England's domination of American high culture reached its peak. ${ }^{4}$ The poet must have been gratified to read Garland's reports of his growing following in Boston, a city whose district attorney in 1882 had declared his poetry to be obscene literature, banning Leaves of Grass from the mails. For Whitman, who always expected to be appreciated by westerners, it must have seemed fitting that two of his main Boston promoters were recently transplanted midwesterners: Garland himself and William Sloane Kennedy. Garland's letters-accurate although slightly overstated because of his desire to bolster Whitman in his declining 
years - provide an important record of how New England journalists, students, and lecture audiences responded to Whitman. In the 1880s, when the poet's creative powers were waning, the Boston suppression controversy and the later promotional efforts of Garland and his friends kept Whitman's name constantly before the New England public. The attention given to Whitman no doubt helped him win the interest and respect of the Harvard poets (particularly George Cabot Lodge, William Vaughn Moody, and to some extent George Santayana), who were the first American poets to make significant use of Whitman's example.

\section{Texas AEM University \\ Louisiana State University in Shreveport}

\section{NOTES}

1 Unpublished letter, the Feinberg-Whitman Collection, the Library of Congress. For earlier studies of the Whitman-Garland relationship. see B. R. McElderry, "Hamlin Garland's View of Whitman," Personalist 36 (1955), 369-78; Nancy Bunge, "Walt Whitman's Influence on Hamlin Garland," Walt Whitman Review 23 (1977), 45-50; and Thomas Becknell, "Hamlin Garland's Response to Whitman," The Old Northwest [Oxford, Ohio] 7 (1981), 217-235.

2 Garland's holograph letter written 10 or 11 January 1889, is in the Oscar Lion Collection of the New York Public Library. The holographs of all other letters printed here can be found in the Feinberg-Whitman Collection, the Library of Congress.

3 Kenneth M. Price, "Hamlin Garland's 'The Evolution of American Thought': A Missing Link in the History of Whitman Criticism," Walt Whitman Quarterly Review 3 (Fall 1985), $1-20$.

4 Martin Green, The Problem of Boston: Some Readings in Cultural History (New York: W. W. Norton, 1966), p. 121.

5 For discussions of Whitman's impact on the Harvard poets, see John W. Crowley, "Whitman and the Harvard Poets: The Case of George Cabot Lodge," Walt Whitman Review 19 (1973), 165-168, and David Perkins, A History of Modern Poetry (Cambridge: Harvard University Press, 1976), p. 105.

Letter 1

Ms: 6 pp., als. Pbd: Traubel, 2:160-162; Garland, Roadside Meetings, pp. 128-130.

Jamaica Plain

Boston,

Mass.

Mr. Walt Whitman.

$11 / 24 / 86$

It is with profound sorrow that I read in the papers the news that you are again suffering from your old trouble. ${ }^{1}$ I trust it is not so serious as reported. My regard for you is so great that I am very sorry, not to be able to buy more copies of your books and thus give a more substantial token of sympathy. 
I am an enthusiastic reader of your books, both volumes of which I have within reach of hand. ${ }^{2} \mathrm{I}$ am, everywhere in my teaching and writing, making your claims felt and shall continue to do so. ${ }^{3}$ I have demonstrated (what of course you know) that there is no veil-no impediment - between your mind and your audience, when your writings are voiced. The formlessness is only seeming not real. I have never read a page of your poetry, or quoted a line, that has not commanded admiration. The music is there and the grandeur of thought is there, if the reader reads, guided by the sense and not by the external lining or paragraphing. Even very young pupils feel the thrill of the deep rolling music though the thought may be too profound for them to grasp.

In a course of lectures before the Boston School of Oratory last summer I made a test of the matter. ${ }^{4}$ I do not think a single pupil held out against my arguments supplemented by readings from your work. The trouble is they got at your work through the daily press or through the defenders of Longfellow or Tennyson (whom it is supposed you utterly antagonize). ${ }^{5}$ When it is brought to them by one who appreciates and measurably understands your methods and ideals I do not think there is any doubt of the favorable result. I have found much opposition but it was mostly ignorant or misled.

I am a young man of very ordinary attainments and do not presume to do more than to give you a glimpse of the temper of that public which would not cio you wrong, deliberately, but who by reason of the causes hinted at above, fail to get at the transcendent power of Leaves of Grass.

If I have given you the impression that I believe in you and strive to interpret you, you will not feel that I have over-stepped the privileges of a pupil in the presence of a great teacher.

The enclosed slip is a meagre out-line of a volume which I am writing and which I hope to get out this coming spring. As the motto-page of this volume I have used a paragraph from your "Collect" which is entitled "Foundation Stages - then Others." 6 While it is not strictly essential to the book, yet I should esteem it a favor if you would consent to its use. One sentence, "In nothing is there more Evolution than in the American mind," I have also used in company with Spencer's great law of progress upon my title page. ${ }^{7}$ It helped to decide the title, which is: The Evolution of American Thought: an outline study of the leading phases of American Literature etc. In the latter part of the volume I have treated of the Age of Democracy and its thought, taking as foundation the splendid utterances of $M$. Taine upon the modern age. It is in this chapter that I place your work. ${ }^{8}$ I quote from you quite largely both in treating of your writings and in treating the general theme of present and future democratic ideals. I hope to be able to please you with my treatment of your great work. Beside this I am preparing special lectures upon the same subject.

Have you any objection to the quotations which I find it necessary to use? In conclusion let me say that without any bias in your favor, (rather the opposite from newspapers) your poems thrilled me, reversed many of my ideas, confirmed me in others, helped to make me what I am. I am a border man; born in Wisconsin and raised on the prairie frontier. I am a disciple of $\mathrm{Mr}$. Spencer and therefore strive at comparative methods of criticism. That your poems should thus convert me, is to me a revelation of their power, especially when I can convince others in the same manner.

And now revered friend (for I feel you are a friend) think of me as one who radiates the principles of the modern age, and who will in his best manner (poor at best) strive 
to make his hearers and readers better aware of the goodness and grandeur of the "Good Grey Poet" and his elemental lines.

Your readers are increasing, and may you live to see the circle infinitely extended, is my fervent hope. I do not expect a reply to this other than the signification whether I may quote you or not. I wish I might see and talk with you but that is not possibleexcept through your volumes.

I am most sincerely yours,

Hamlin Garland.

1 The "old trouble" is Whitman's paralytic stroke. On 19 November 1886 Whitman wrote William Douglas O'Connor, "I go out by my own volition not at all, as my power of walking \&c. is quite gone" (Walt Whitman: The Correspondence, ed. Edwin Haviland Miller [New York: New York University Press, 1969], 4:54).

2 Garland owned at this time both Leaves of Grass and Specimen Days. Garland's marked copy of Leaves of Grass (Boston: Osgood, 1881) is in the Hamlin Garland Papers at the University of Southern California Library.

3 Garland refers to his teaching at the Boston School of Oratory and, probably, to his unpublished history of American literature entitled "The Evolution of American Thought." For the text of the chapter dealing with Whitman, see Price, "Hamlin Garland's 'The Evolution of American Thought," "pp. 5-18.

4 Shortly after arriving in Boston from South Dakota in October 1884, Garland attended a lecture by Moses True Brown on "The Philosophy of Expression" at the Boston School of Oratory. After becoming acquainted with Garland, Brown, the school's principal, offered him free tuition in exchange for proofreading, translation, and research assistance with a manuscript he was preparing for publication. In May, Garland was made instructor in literature for the school's summer session; he was subsequently offered a full-time teaching position for the 1885-86 school year. During the fall term Garland first taught a course in American literature. His tenure at the Boston School of Oratory lasted until the fall of 1891, when, after the publication and generally successful reception of Main-Travelled Roads, Garland decided to devote his time exclusively to writing and public lecturing. For his account of his early experiences at the Boston School of Oratory, see $A$ Son of the Middle Border (New York: Macmillan, 1917), chapter 27.

5 For Garland's comments on Longfellow and his poetic contemporaries, see Price, p. 10. Early in his career Whitman was, for the most part, sharply critical of his poetic contemporaries. For example, he asked in "Democratic Vistas": "Do you call those genteel little creatures American poets? Do you term that perpetual, pistareen, paste-pot work, American art. . . ?" (Prose Works 1892, ed. Floyd Stovall [New York: New York University Press, 1964], 2:388-389). Hence the influential poet and critic Edmund Clarence Stedman was justified when he wrote that Whitman's "intolerant strictures upon the poets of his own land and time have made them hesitate to venture upon the first advances in brotherhood. . . [ [H]is opinion of their uselessness has been expressed in withering terms" (Scribner's Monthly 21 [November 1880], 60, 62). Following Stedman's criticism and the deaths of Bryant in 1878 and Emerson and Longfellow in 1882, Whitman became more conciliatory in such pieces as "My Tribute to Four Poets," a chapter of Specimen Days.

6 The "enclosed slip" is not extant. "Foundation Stages - then Others" first appeared as paragraph ten of "Thoughts for the Centennial" in Whitman's Two Rivulets (1876). The piece was reprinted in Specimen Days $\mathcal{E}$ Collect (1882). 
7 Garland is probably referring to Herbert Spencer's belief that mankind was slowly but inexorably moving toward social perfection. In Social Statics (1851) Spencer wrote: "Always toward perfection is the mighty movement-toward a complete development and a more unmixed good, subordinating in its universality all petty irregularities and fallings back, as the curvature of the earth subordinates mountains and valleys."

8 Garland read Hippolyte Taine's History of English Literature during the winter of 18831884 and was much impressed by his theories regarding race, milieu, and epoch.

\section{Letter 2}

Ms: 4 pp., als.

Jamaica Plain, April 19/88

Walt Whitman:

Dear Sir: It is probable that my friend Kennedy ${ }^{1}$ has told you something of me and the work I am trying to do for you and for American literature. I have not written to you for the reason that you are sufficiently plagued with letters but now I feel that I have reached the point where I can presume on your interest. Mr. Kennedy I know writes to you in a depressed mood many times, saying that he finds a "solid line of enemies" (I think those were his words). This is not true of my experience. I am often astonished at finding so many friends and sympathizers in your work and cause. In my teaching and lecturing I find no difficulty in getting converts to the new doctrine and find your poems nearly irresistible in effect. True they do not always agree that they are "poems" though acknowledging their power and beauty. I do not care what they call them (I say to them) and receive their allegiance just the same. I hope to do much in the way of reading and lecturing to bring your work before the people and it would give me pleasure to know you consider my work valuable. I am just now delivering a course of lectures in the city on "The Literature of Democracy" concerning which I enclose a couple of slips. ${ }^{2}$ In these I am trying to analyze certain tendencies of American life somewhat in accordance with the principles you have taught. How successful I may be remains to be seen.-

I have not seen Mr. Kennedy for some months, he is so busy these days, but I had a characteristic letter from him a few days ago.

I have the greatest hope of seeing you some day and to talk with you upon these matters face to face. Let me assure you again that there is everywhere a growing respect and love for you and a growing appreciation of your poems. The papers no longer ridicule or even condemn unreservedly. An acquaintance among the younger literary editors of the city warrants me in saying that there is much more sympathy and appreciation among them than our friend Kennedy realizes. There is great gain.

It would give me great pleasure to hear from you if you are able to write.

With greatest love and esteem,

\section{Hamlin Garland.}

1 At this time William Sloane Kennedy (1850-1929), another Whitman admirer from the midwest, was at work on a study entitled "Walt Whitman, Poet of Humanity." Kennedy later wrote Reminiscences of Walt Whitman (1896), A Companion Volume to Leaves of Grass (1926), and edited Walt Whitman's Diary in Canada (1904). In "A Backward Glance O'er Travell'd Roads" Whitman chose to quote Kennedy's negative account of the reception of Leaves of 
Grass - "I find a solid line of enemies to you everywhere"-rather than the more positive account Garland offers in this letter. The evidence about Whitman's reception was in fact mixed; the poet's own preference for Kennedy's bleaker and more melodramatic account is one of the many indications that Whitman cultivated his role as a misunderstood genius. See Leaves of Grass, Comprehensive Reader's Edition (New York: New York University Press, 1965), p. 562.

2 Garland may have included with his letter either notices from Boston papers about his lectures on "The Literature of Democracy" (a chapter from "The Evolution of American Thought") or an advertising brochure such as the one reproduced by Lars Ahnebrink in The Beginnings of Naturalism in American Fiction (Cambridge: Harvard University Press, 1950), pp. $440-441$.

\section{Letter 3}

Ms: 2 pp., als. Pbd: Traubel, 2:509.

Jamaica Plain, Oct. $18 / 88$.

Dear Mr. Whitman:

I began a course of twelve class lectures in Waltham yesterday in which I take up "Walt Whitman's Message."1 I never have any difficulty in obtaining respectful listeners upon that theme. I hope to speak many times upon it. I had a very friendly letter from Mr. Burroughs $-{ }^{2}$ I am sorry I did not see him as I came through. ${ }^{3}$ I want to say also that I did not write that little notice of your book in Transcript. ${ }^{4} \mathrm{I}$ am waiting till you send that autograph copy-then I will write a goodly review for Transcript or elsewhere. ${ }^{5}-\mathrm{I}$ have not seen Kennedy since returning-nor Baxter. ${ }^{6}$ Hope to do so soon. At earliest possible moment I intend to get that article into shape concerning your work as a landscapist. ${ }^{7}$ I do hope you'll keep gaining in strength -as Burroughs worte me you were.

With greatest esteem, Hamlin Garland

1 Little is known about Garland's class lectures in Waltham, though he probably based his talks either on his teaching notes from the Boston School of Oratory or on this writings about the poet in "The Evolution of American Thought."

2 The naturalist John Burroughs (1837-1921), author of Notes on Walt Whitman as Poet and Person (1867), had written to Garland on 16 October 1888: "I am very glad to see the rising men like you espousing Whitman's career. I congratulate you. It is a battle for the young to win. When I was younger \& the odds were much greater than they are now I took a hand in, but I look upon the matter more dispassionately now, I feel more inclined to let things take their own course, which means I suppose that I am getting old" (Hamlin Garland Papers, USC).

3 Garland had visited Whitman in Camden on 26 September 1888, and had stayed for half an hour after being instructed by Whitman's doctor to stay only two minutes. For Whitman's account of this visit, see Horace Traubel, With Walt Whitman in Camden (New York: D. Appleton, 1908), 2:383-384.

4 On 7 October 1888, Whitman sent William Sloane Kennedy a pre-publication copy of November Boughs, which David McKay would bring out the following week (Correspondence, 4:220). Kennedy reviewed November Boughs in "Whitman's New Volume," Boston Evening 
Transcript, 17 October 1888, p. 5. He noted that some of the poems reveal Whitman's "full power" but others "show marks of the advancing lethargy of age."

5 On 15 November 1888-less than a month after Kennedy reviewed November BoughsGarland also reviewed this book for the Boston Evening Transcript in "Whitman's November Boughs,'” p. 6, praising the poet's gift for titles and his calm, patient, and philosophical outlook. He concluded his review with both praise and a call for material assistance for the poet: "We should hasten to do him honor while he is with us. Praise too often builds monuments when it should buy bread; furnishes tombstones when it should warm houses."

6 Sylvester Baxter (1850-1927), a publicist and author (The Cruise of a Land-Yacht [1891], Old Marblehead [1906], The Unseen House [1917] and other works) met Garland probably in 1887 at the home of Edgar Chamberlain of the Boston Evening Transcript. Baxter was also a friend and correspondent of Whitman's. During Whitman's visit to Boston in 1881, Baxter attended a production of Romeo and Fuliet with him. Baxter described Whitman's visit in "Walt Whitman. His Second Visit to the New England Metropolis. A Cordial Welcome in Literary Circles. Sketch of His Life and Poetic Characteristics," Boston Herald (18 April 1881), Supplement, p. 1, and "Walt Whitman in Boston," New England Magazine 6 (August 1892), 710-714. Baxter also wrote other articles on Whitman and reviewed Leaves of Grass and Complete Works. In December, 1886, Baxter had proposed to Whitman plans to secure a pension for the poet and to form with other supporters a "Whitman Society."

7 In the late 1880s Garland frequently gave what he called "Lecture Studies in American Literature and Art" (advertising brochure in the Feinberg-Whitman Collection, the Library of Congress). These lectures were working drafts of chapters Garland intended to include in "The Evolution of American Thought." In the 1889-1890 season, Garland advertised a lecture entitled "The Literature of Democracy: The Genre and Landscape Poetry of Whitman." The Garland Papers at USC contain what appears to be a later version of this piece-entitled simply "The Literature of Democracy" - but this version has virtually nothing to say about Whitman as a landscapist.

\section{Letter 4}

Ms: 2 pp., als. Pbd: Traubel, 2:530.

Dear Mr. Whitman:

Jamaica Plain, Oct $24 / 88$.

I am over-joyed to receive your volume and autograph. Be sure it will be read and heralded to the world. I saw Mr. Howells yesterday. Spent the afternoon with him in discussing reforms, literary progress etc. ${ }^{1}$ He spoke of you again with a good deal of feeling. I think it of very great importance that you send him an autograph copy of November Boughs. ${ }^{2}$ If it has not been done dont fail to do it at once. If you send it immediately upon receipt of this letter address

W. D. Howells

Little Nahant

(near Lynn) Mass.

If you do not send till next week address

W. D. Howells

330 East 17th st.

New York City. ${ }^{3}$ 
And I will write to him again about it. He is more than friendly to you and all progressive movements.

\author{
With deepest regard- \\ Hamlin Garland
}

1 Garland had written "Lemuel Barker," a very positive review of William Dean Howells's novel The Minister's Charge in the Boston Evening Transcript, 31 January 1887, p. 6. He was anxious to meet "the Dean of American Letters," and, after receiving a letter of introduction from Edward Clement, the editor of the Transcript, he made the short trip to Lee's Hotel in Auburndale, Massachusetts, to visit Howells. In a letter of 2 May 1887, to Whitelaw Reid, Howells noted: "A Mr. Hamlin Garland has called upon me, and has greatly interested and impressed me by his view of literature" (Selected Letters of W. D. Howells, ed. Robert C. Leitz, III [Boston: Twayne, 1980], 3:187). Howells and Garland, in addition to being fellow midwesterners, came to share similar social and literary views. Howells recalled their first meeting in "Mr. Garland's Books," North American Review 196 (October 1912), 523-528: "I suppose we were friends in the beginning, and never foes, because he had strong convictions too, and they were flatteringly like mine. When we first met ... there was nothing but common ground between us, and our convictions played over it together as freely and affectionately as if they had been fancies." Garland wrote accounts of his meetings with Howells in $A$ Son of the Middle Border, Roadside Meetings, and "Meetings With Howells," Bookman 45 (March 1917), 1-7. See also Hamlin Garland's Diaries, ed. Donald Pizer (San Marino: The Huntington Library, 1968), pp. 148-157, and the many reviews Garland wrote of Howells's novels.

2 Howells reviewed November Boughs in the "Editor's Study," Harper's Monthly 78 (February 1889), 488. While Howells objected to Whitman's "gospel of nudity," he was otherwise favorably impressed by Whitman's volume.

3 Howells resided in Little Nahant during the summer of 1888; in November he returned to New York.

\title{
Letter 5
}

Ms: 3 pp., als. Pbd: Traubel, 3:67.

Jamaica Plain, Nov. 9/88.

Dear Mr. Whitman:

I talked last night to my Waltham class (of forty ladies) about your work and read to them. I wish you could have seen how deeply attentive they were and how moved by "Out of the Cradle" "To Think of Time" "Sparkles from the Wheel" and others. Many of them will now read your works carefully and understandingly. I told them to come at you through Specimen Days. I always advise my pupils so. After reading your prose they are better prepared to sympathize with your poetic views. I am much pleased with November Boughs and expect to do quite a good review soon. Mr. Clement of the Transcript is a personal friend and is quite kindly disposed toward your work. ${ }^{1}$ Indeed, all the leading men on the Transcript are. - Baxter is away. Kennedy I have not seen. Chamberlain is in the library as usual. ${ }^{2}$ I think I told you of the good letter I had from Burroughs.

I hope Mr. Howells will succeed in doing something for November Boughs in December number it is such a great number usually.

It rejoices me to think you are gaining. I hope the winter will not be too severe for 
you - though I believe you stand the cold better than the heat. I hope to hear a word from you occasionally.

Very sincerelyHamlin Garland

1 Edward H. Clement (1843-1920) was assistant editor (1875-1881) and editor-in-chief (1881-1906) of the Boston Evening Transcript. Garland met Clement shortly after he had his review of Howells's The Minister's Charge accepted for publication in the Transcript.

2 Joseph Edgar Chamberlain (1861-1935) was a member of the editorial staff of the Transcript and author of The Listener in the Country (1896), The Listener in the Town (1896), The Ifs of History (1907), and The Boston Transcript: A History of Its First Hundred Years (1930).

\section{Letter 6}

MS: 2 pp., als. Pbd: Traubel, 3:114.

\section{Dear Mr. Whitman:}

Jamaica Plain, Nov. $16 / 88$.

I send copy of the Transcript containing a notice of your work. It is not intended to be a study or an elaborate review simply a good word which will allay if possible some of the antagonism which still exists toward your work. I shall do more of course but this little notice has its work to do. I send copies to Mr. Howells and to Mr. Burroughs. I hope you are feeling as well as when you last wrote. - I saw Judge Chamberlain and other of our friends today. ${ }^{1}$ Called on O'Reilly but he was out. ${ }^{2}$ Hope to see him soon. I hope to do something specially useful for you by and by.-Baxter has returned from Europe. I shall see him in a day or two at his home.

Steadfastly, Hamlin Garland

1 Mellen Chamberlain (1844-1900) served as judge and chief justice of the Boston municipal court from 1866 until 1878; from 1878 until 1890 he was librarian-in-chief of the Boston Public Library.

2 John Boyle O'Reilly (1844-1890), an Irish-born editor of the Boston Pilot (1876-1890) and poet (Songs from the Southern Seas [1873], In Bohemia [1886], and other books of poetry), was one of the original members of the "Whitman Society" and the treasurer of the "Cottage Fund," organized to purchase a summer cottage for Whitman.

\section{Letter 7}

Ms: 4 pp., als. Pbd: Traubel, 4:78-79.

[? Jamaica Plain]

[January 10 or 11,1889$]^{1}$

Dear Mr. Whitman,

I have words occasionally from you and it gives me great pleasure to know you are so comfortable. -I get a card from Kennedy semi-occasionally, he seems to be very busy. I passed a pleasant evening with Mrs. Louise Chandler Moulton, the present 
week, and we had some considerable talk of you. ${ }^{2}$ She is an appreciative admirer of your work and prizes the chat she had with you last year. She writes a literary letter to the Herald each Sunday and gets in a telling touch once in a while on your work. She is a very charming and able woman. Your stalwart supporter Judge Chamberlain of the Public Library, I see frequently, a very thoughtful and fearlessly out-spoken man. He does some valuable historical lecturing and often says some inspiringly good things about our artificiality in poetry and the drama.

I wonder if it ever occurred to you that our novel and drama is now slowly changing base, coming around to the "idealization of the real." The whole out-look to me is full of hope. I think I see in what our aristocratic friends are pleased to call "vulgarity in fiction and the drama," the sure sign of the native indigenous literature we have waited for. If I could ever get to see you I should take pleasure in enlarging upon this. It forms the staple for a number of my lectures on the Literature of Democracy-

Our friend Baxter had an extended notice of "Complete Works" in Herald, you saw it of course. ${ }^{3}$

filially yours

Hamlin Garland

1 On 12 January 1889 , Whitman wrote to Richard Maurice Bucke indicating that he had just received a letter from Garland (Correspondence, 4:267-268).

2 Ellen Louise Chandler Moulton (1835-1908), an editor, poet, and short-story writer, had corresponded with Whitman since 1876 and had visited him in Camden on 23 April 1888; she wrote of their meeting in "Three Very Famous People. Mrs. Cleveland, George W. Childs and Walt Whitman. Words of Washington and Philadelphia. Poet Who Wrote of the Birds on Paumanok's Shore," Boston Sunday Herald, 29 April 1888, p. 20. Though she had words of praise for Whitman and his work, Whitman said of her, "I can't endure her effusiveness: I like, respect her: but her dear this and dear that and dear the other thing make me shudder" (Traubel, 4:246). In all likelihood Garland met Moulton in his Boston literary circles.

3 Sylvester Baxter's review, "Whitman's Complete Works," appeared in the Boston Herald, 3 January 1889 , p. 4 . He was lavish in his praise for the volume, remarking that this edition is "monumental in our literature."

\section{Letter 8}

Ms: 3 pp., als. Pbd: Traubel, 4:491-492.

[Jamaica Plain]

[? April 3, 1889]

Dear Mr. Whitman:

I saw lately that you were not so well-but hope it is a newspaper report merely and that you are continuing to gain. I saw Mrs. Dr. Spaulding recently. ${ }^{1}$ She is doing all she can for the acceptance of $L$. of $G$. -By the way I found a lover where I least expected it, in Mr. Hezekiah Butterworth of the Youth's Companion, who said when I encited him to hear me lecture upon your work, "I shall come by all means. I think Whitman one of the greatest if not the greatest of our American poets." $2 \mathrm{He}$ is not afraid of your work but wishes some of it were left out of it, for a popular volume. He would think it all right in itself I presume-Mrs. Moulton has gone south for a month. Returns in May. I hope she may be able to see you before she sails for Eng- 
land in June. -Kennedy I never see now. Don't know what he is doing. I should like to see him very much. I am digging away in a way to earn a living. I gave two evenings to your work before my class at New England Conservatory. My class is composed of about fifty bright young girls studying music. You see I am not afraid to carry your word to anyone. To me there is not a line that has a downward tendency. Still I recognize the fact that to many people "A woman waits for me" is wholly inadmissible, and I know that the rest of the book is a sealed book to them-perhaps it would be anyway-there's consolation there. ${ }^{3}$ I shall have Specimen Days in my class during spring term.

With greatest esteem Hamlin Garland

1 Mrs. A. H. Spaulding, of Boston, was an admirer of Whitman who praised him publicly. On 17 March 1889 she visited Whitman in Camden; upon her return to Boston she wrote to thank him for the visit and, on 28 March, she sent Whitman flowers.

2 Hezekiah Butterworth (1839-1905) was assistant editor (1870-1904) of The Youth's Companion, a prominent weekly magazine for children published in Boston. Garland published two poems in The Youth's Companion in 1889: "A Dakota Wheat Field" appeared in the July 18 issue; "By the River" came out in the August 15 number.

3 In 1882, "A Woman Waits for Me" and "To a Common Prostitute" were two of the poems regarded as most offensive when the Boston district attorney officially classified Leaves of Grass as obscene literature.

\section{Letter 9}

MS: 1 p., als.

Dear Mr. Whitman:

Jamaica Plain, May 28/89

I shall be with you on you seventieth birthday nothing intervening. ${ }^{1}$ Kennedy cant come. I dont know whether Mr. Butterworth will or not but he was much interested in the project and hoped the results would be satisfactory. I speak in Philadelphia in the evening but that will not interfere with my attendance at the dinner. I hope Mr. Howells can go down.

Sincerely

Hamlin Garland

1 Garland attended Whitman's seventieth birthday celebration at Morgan's Hall in Camden on 31 May and gave a brief address praising Whitman's themes of "Optimism and Altruism-Hope for the future and Sympathy toward men." Howells did not attend the birthday celebration, but he sent a letter of tribute. 


\section{Letter 10}

MS: 2 pp., als.

Dear Mr. Whitman:

[Jamaica Plain]

[? June 1889]

I send you a few pages of notes which I intend printing if you do not object. ${ }^{1}$ I want the authority to say some of these things. They will do you good. The first few pages will be taken up with a bit of description of the Banquet and so on. The rest of the letter is a free report of what we talked about in my visits to you. If any part of this displeases you, or misrepresents you-mark it-or indicate it to $\mathrm{Mr}$. Traubel and return it to me. ${ }^{2}$

Hartman and others have done so much to misrepresent you in the papers that I wish to present something counter which shall help men to understand you. ${ }^{3} \mathrm{I}$ wish you would read $\mathrm{Mr}$. Howells later books and essays. He is taking fearlessly high grounds.

If you dont feel like writing, ask Traubel to reply.

Everybody here sends well-wishes - Baxter, Chamberlain, Clement etc-

With greatest esteemHamlin Garland

1 Garland sent Whitman a typescript entitled "Whitman at Seventy" (Hamlin Garland Papers, USC), which was later published in the New York Herald, 30 June 1889, p. 7. Whitman, as was his practice, carefully revised Garland's essay, changing it in subtle but important ways. For example, Garland's typescript quotes Whitman as saying that most American writing lacks a distinctive national twang: "Most of it might have been written in England or on the continent." Whitman allowed this passage to stand but added a conciliatory remark: "I myself like Cooper, Bryant, Emerson, and Whittier."

2 Horace L. Traubel (1858-1919) had known Whitman since 1873, when the poet had first moved to Camden. Beginning in 1888, Traubel made almost daily visits to Whitman, engaging in conversations that led to Traubel's multi-volume With Walt Whitman in Camden.

3 Carl Sadakichi Hartmann (1869-1944) published "Walt Whitman. Notes of a Conversation with the Good Gray Poet by a German Poet and Traveller" in the New York Herald, 14 April 1889 , p. 10. Whitman felt that Hartmann had done him a disservice and complained in a letter to William Sloane Kennedy about "That infernal farrago of my opinions!! in the Herald" (Correspondence, 4:331).

\section{Letter 11}

Ms: 2 pp., als.

Dear friend:

[Jamaica Plain]

[? June 1889]

I sent my article on you to Walsh some weeks ago-have not heard from him but assume he will use it soon. ${ }^{1}$ I will write him again if I do not hear this week. I thought it but fair that he should print an authentic report. He has printed so many that were not true. 
I am very busy lecturing and writing now. I want to get out a volume of stories this fall-stories illustrative of the west and of social injustice. I am now bargaining with Roberts Bros. thereto. ${ }^{2}$

I am also writing dramas-my fourth and last is praised highly by practical managers and literary critics. ${ }^{3}$ I shall try to bring that out next spring. -

I send you my photo-it may be of interest to you-I had just been lecturing upon your prose and the book in my hand is Specimen Days.

With deepest wishes for your good health, Hamlin Garland.

1 William S. Walsh (1854-1919) was editor of Lippincott's Magazine (1885-1889) and literary editor of the New York Herald. He published Garland's article on Whitman's birthday dinner.

2 Garland's Main-Travelled Roads: Six Mississippi Valley Stories was not published until 1891 by the Arena Publishing Company of Boston.

3 Garland's fourth drama has not been identified. There are three fragments of plays written by Garland in the Hamlin Garland Collection at USC. Only one of his plays was published: "Under the Wheel: A Modern Play in Six Scenes" appeared in Benjamin Orange Flower's muckraking magazine Arena 2 (July 1890), 182-228; it was published in book form as Under the Wheel (Boston: Barta Press, 1890).

\section{Letter 12}

Ms: 2 pp., als.

Dear Walt Whitman:

April 15/90.

12 Moreland st Roxbury, Boston.

I have seen reports that you were not so well just now, as we all hoped you'd be at opening of spring. Let me send as a spring message (as I sent a year ago) I find everywhere a growing respect and even tenderness for you. I have spoken several times during the year upon your work and have made converts always. The mere reading from some of your pages serving to open the eyes of my hearers. I am perfectly certain that this will be my spring message as long as you stay here with us. - As for myself I am hard at work and beginning to succeed with the Century, Harpers, Arena etc. ${ }^{1}$ I am still too poor to do what I'd like in the way of having a copy of each edition of your works. I hope to be able to do soon. Please give my regards to Traubel and other friends. Ask him to send me a line if you do not feel like writing.

With deepest regards, Hamlin Garland

1 Garland had published two stories in Harper's Weekly in 1889, "Under the Lion's Paw" (33 [7 September], 726-727) and "Old Sid's Christmas" (33 [28 December], 1038-1040), and had two more awaiting publication in that magazine in 1890, "Drifting Crane" (34 [31 May], 421422 ) and "Among the Corn-Rows" (34 [28 June], 506-508). In addition to publishing "Under the Wheel," in 1890 Arena also brought out a critical article by Garland entitled "Ibsen as a Dramatist," 2 (June), 72-82, and a short story, "The Return of a Private," 3 (December), 97113. 